\title{
Chapter 19 \\ Participatory Sustainability Research for Risk Management and Leadership Development
}

\author{
Masanori Kobayashi
}

\begin{abstract}
Effective risk management and sustainability promotion require proper assessment of the environment and social capacity for managing the environment. National governments and international agencies provide monitoring data on the environment such as data relating to air and water quality, forest cover, land, biodiversity, and waste management. While local communities and stakeholders need to play a vital role in managing risks and promoting sustainability at the field level, however, they often lack scientific information. Instead they rely on the experiential and observation-based information that is often the most useful in communicating to other community members and stakeholders. Participatory assessment can therefore provide a useful tool for community members and stakeholders to comprehend environmental risks and challenges in promoting sustainability. Meanwhile, the feedback from the communities and stakeholders constitutes useful information for decision-makers and practitioners to plan and facilitate transformation in policies and institutions in order to improve environmental risk management and promote sustainability.
\end{abstract}

Keywords Environmental risks $\bullet$ Leadership development $\bullet$ Social capacity assessment

- Stakeholder participation $\bullet$ Sustainability

\footnotetext{
M. Kobayashi $(\varangle)$

Graduate School of Environment and Information Sciences,

Yokohama National University, Yokohama, Japan

e-mail: m-kobayashi@ynu.ac.jp
} 


\subsection{Introduction: Environment and Social Capacity Assessment for Effective Environmental Risk and Sustainable Resource Management}

It has long been acknowledged that local communities and stakeholders have a vital role to play in protecting the environment, managing risks, and promoting sustainable use of natural resources, and environmental issues are best handled with the participation of all citizens concerned, as reaffirmed in the Rio Declaration adopted at the United Nations Conference on Environment and Development (UNGA 1992). Ostrom (1990) refers to participatory environmental management by characterizing it as management of common pool resources by non-governmental actors. Ostrom (2000) further articulates the features of self-governance of natural resources. Ostrom asserts that the presence of leaders or entrepreneurs is an important factor in instigating social mobilization, structuring governance mechanisms, and promoting collective actions to manage the environment and natural resources.

When developing and operationalizing self-governing mechanisms for environmental management or sustainable natural resource use, the role to be played by leaders or entrepreneurs is paramount, but emphasis is also given to the utility of involving external facilitators in similar processes (APFED 2010). The latter supplement the leaders or entrepreneurs, who can be endogenous. External facilitators are involved in raising awareness among local community members and stakeholders, organizing them, and institutionalizing collaborative management of the environment and natural resources. They can play an instrumental role in identifying and providing options for interventions in addressing environmental risks or sustainability challenges. It is however important to note the caveat that the external facilitators also need to understand the local conditions and context (Adandedjan and Niang 2006). They are not supposed to impose their own preconceived notions of collective actions on community members and stakeholders (Sow and Adjibade 2006). It must be the local community members and stakeholders who make the final decisions on the modalities of collective actions.

It is a core purpose of sustainability science to understand the mechanisms of natural resource use and impacts on the environment and livelihoods. To carry out effective sustainability science, it has been suggested that multi-disciplinary expertise should be brought together to facilitate in-depth transformation of the way scientific research is organized (Dedeurwaerdere 2013). Integration of science and knowledge about natural and social systems has evolved to become sustainability science (Rockström et al. 2009; Blackstock et al. 2007; Yasunari 2013) and a platform has been established to promote science-policy interface on sustainability (Takeuchi 2013). Sustainability science is said to consist of two key components, namely a descriptive analytical mode based on an advanced form of complex system analysis, and a transformation mode oriented toward developing practical solutions for sustainability problems. An increasing emphasis is now given to the latter component to facilitate a socio-economic transition toward achieving stronger sustainability (Dedeurwaerdere 2013). 
If the participatory appraisal for the environment and ecosystems can be undertaken using a simple and indicative assessment approach, such a process can provide a useful tool as well as a step toward commencing dialogues for stakeholder/ community leaders, scientists, and practitioners. Such dialogues can address how to improve environment/ecosystem management and livelihoods as a preliminary stage in participatory learning and action (PLA), or participatory sustainability science (PSS) research. The participatory appraisal process can also provide a meaningful opportunity for students to acquire holistic viewpoints on sustainability and develop the analytical and facilitation skills required for environmental leaders by confronting reality and being required to comprehend the complexity and dynamism intrinsic to sustainability conundrums. In practice, however, PLA or PSS research does not always lead to the intended outcome due to either poor conflict resolution or insufficient facilitation (Blackstock et al. 2007) and there are a number of challenges in integrating PLA or PSS into environmental leadership training programs. This paper aims to outline the genesis and evolution of PLA or PSS, its advantages, and the challenges in applying it in environmental leadership development at universities.

\subsection{Genesis and Evolution of Participatory Sustainability Science}

There has been a looming question about the extent to which researchers and university scholars can carry out sustainability science with greater impacts on society. The participatory rural appraisal (PRA) approach that spread and evolved in the 1980s developed as a method to learn about rural livelihoods from, with, and by rural people (Chambers 1994a) or to enable local people to share, enhance, and analyze their knowledge of life and environmental conditions, to plan, and to act (Chambers 1994b). PRA emanated from preceding currents such as activist participatory research that aims to enhance people's awareness and confidence and to empower their actions. With the increased proactive involvement of local people in learning processes, the scope of PRA was expanded and it was renamed "participatory learning and action" in the 1990s (Chambers 2007). In addition, a number of other developments have emerged and been promoted as PSS. These include generation of knowledge about sustainability from multiple stakeholders, attempts to prompt changes in personal and institutional behaviors, and a transition toward sustainability (Blackstock et al. 2007). The evaluation framework for PSS research is structured with multiple components including the level and modalities of stakeholder collaboration that changed people's behaviors, norms, and culture (Blackstock et al. 2007).

Lately, a participatory sustainability research framework with an articulate focus on the environment, natural resources, and local livelihoods has been applied. A variety of multi-ecosystem service assessment techniques have been developed and practiced (Kelvin et al. 2013). Multi-ecosystem service assessment techniques are mainly based on the framework provided by Millennium Ecosystem Assessment 2005. 
Table 19.1 Ecosystem services and drivers of change

\begin{tabular}{|c|c|c|}
\hline Ecosystem services & Direct drivers & Indirect drivers \\
\hline $\begin{array}{l}\text { 1. Provisioning (e.g., food, } \\
\text { water, fiber and fuel), } \\
\text { 2. Regulating } \\
\text { (e.g., climate regulation, } \\
\text { water, and disease), } \\
\text { 3. Cultural (e.g., spiritual, } \\
\text { aesthetic, recreational } \\
\text { and educational) and } \\
\text { 4. Supporting (e.g., primary } \\
\text { production and soil } \\
\text { formation) }\end{array}$ & $\begin{array}{l}\text { 1. Changes in local land } \\
\text { use and cover, } \\
\text { 2. Species introduction } \\
\text { or removal, } \\
\text { 3. Technology adaptation } \\
\text { and use, } \\
\text { 4. External inputs } \\
\text { (e.g., fertilizer use, pest } \\
\text { control, and irrigation), } \\
\text { 5. Harvest and resource } \\
\text { consumption, } \\
\text { 6. Climate change and } \\
\text { 7. Natural, physical and } \\
\text { biological drivers } \\
\text { (e.g., evolution, volcanoes) }\end{array}$ & $\begin{array}{l}\text { 1. Demographic, } \\
\text { 2. Economic (e.g., globalization, } \\
\text { trade, market, and policy } \\
\text { framework), } \\
\text { 3. Socio-political } \\
\text { (e.g., governance, } \\
\text { institutional and legal } \\
\text { framework), } \\
\text { 4. Science and technology and } \\
\text { 5. Cultural and religious } \\
\text { (e.g., beliefs, consumption } \\
\text { choices) }\end{array}$ \\
\hline
\end{tabular}

Millennium Ecosystem Assessment (2005)

Millennium Ecosystem Assessment separates the various ecosystem services into four categories, namely (1) provisioning, (2) regulating, (3) cultural, and (4) supporting (Table 19.1). Millennium Ecosystem Assessment presents the direct and indirect drivers that affect ecosystems and delineates the mutual interactions-positive and negative-between ecosystems and humans on different spatial and temporal scales.

Millennium Ecosystem Assessment assessed the changes in major ecosystem service components as "enhanced," "degraded," or "no change in net." The drivers' impacts were assessed as "low," "moderate," "high," or "very high." Meanwhile, the drivers were assessed as "decreasing," "continuing," "increasing," or "rapidly increasing" their impacts. This approach of indicating the drivers' impacts and their changes in simplified terms is deemed pragmatic, particularly in participatory environment/ecosystem assessment. In addition, the Millennium Ecosystem Assessment approach involved assessing the response options for managing ecosystems with particular attention to "government," "business," and "civil society."

Matsuoka et al. (2008) scrutinize the capacity of these three social actors using "social capacity assessment" and "actor-factor analysis." The government, business, and civil society are assessed in terms of their capacity to fulfill the required social system functions with an emphasis particularly on (1) policies and measures, (2) human and organizational resources, and (3) knowledge and technology.

For the United Nations Conference on Sustainable Development (Rio +20 Summit) held in Rio de Janeiro, Brazil, in June 2012, the institutional framework for sustainable development was chosen as one of the two main themes, together with green economy (UNGA 2012). In the outcome document adopted at the Rio +20 Summit, an unequivocal statement was included in paragraph 99 calling for actions to promote access to information, public participation, and justice in environmental matters. While the importance of participation is already emphasized and a number of initiatives have been launched to promote access to information, participation in 
decision-making, and judicial proceedings over environmental matters, many countries still lag behind in developing the required legislation and enforcement mechanisms (Kobayashi 2012). In 2002, the World Resource Institute undertook the first assessment of its kind on access to information, participation in decision making, and judicial proceedings over environmental matters (Petkova et al. 2002). Governments in Asia were urged anew to make environmental information available more proactively, in a format comprehensible to the public, and without the need for a request. At the same time they were urged to enhance transparency through information disclosure to enable the public to participate in decision-making (WRI 2013).

The prioritization and selection of factors that are important in environment and social capacity assessment vary depending on the local conditions and the context of the intended participatory sustainability research (Blackstock et al. 2007). Collective self-reflection through interaction and dialogue among diverse participants supports a cyclical process of observation, analysis, planning, implementation, monitoring, and reviewing based on experiential learning and fosters adaptive management of the environment and ecosystems (Mackenzie et al. 2012). The following section will present further analysis regarding the applicability and challenges of participatory sustainability research. The analysis is based on the experience of implementing a joint research program undertaken by Yokohama National University and the University of Antananarivo.

\subsection{Achievements and Challenges in Applying Participatory Sustainability Research: Field Study in Madagascar}

As a part of the Leadership Development Programme for Sustainable Living with Environmental Risks (the SLER programme), Yokohama National University undertook joint field studies with the University of Antananarivo during 2011-2013. The second joint field study was undertaken from October 27 to November 10, 2012. Preparatory consultation meetings and an outcome presentation symposium took place in Antananarivo on October 28-30 and November 7, respectively, with the field visits from October 30 to November 6. A total of 17 participants, including seven faculty members and ten graduate students from two universities, participated in the field visits (YNU-SLER 2013a, b). The main objective of the field visits was to understand environmental risks and their mechanisms and to observe the intervention measures for reducing risks and promoting sustainability in Madagascar. The participants were separated into two groups and Group A visited the mid-east of Madagascar including Andasibe, Ambatondrazaka, and Alaotra Lake. Meanwhile, Group B visited the north-east of Madagascar including Andapa, Sambava, and Antalaha (the so-called SAVA region-named after the initials of its main cities, namely Sambava, Antalaha, Vohémar, and Andapa ).

The groups undertook (1) an environment/ecosystem assessment, (2) a soil survey, and (3) a social/stakeholder survey (interviews and questionnaire). However, the purpose of this paper is not to present the details of their field research findings. Instead, it 
Table 19.2 Ecosystem assessment in Madagascar-Highlights

\begin{tabular}{|c|c|c|c|c|}
\hline Ecosystem & $\begin{array}{l}\text { Ecosystem } \\
\text { service (resource) }\end{array}$ & Assessment & $\begin{array}{l}\text { Future condition } \\
\text { of resources }\end{array}$ & Reason for the condition \\
\hline \multirow[t]{7}{*}{ Forest } & Fruits & ++ & $\searrow$ & \multirow{7}{*}{$\begin{array}{l}\text { Increasing tree cutting } \\
\text { Expanding forest fires }\end{array}$} \\
\hline & Fuel & +++ & $\searrow$ & \\
\hline & Building material & ++ & $\rightarrow$ & \\
\hline & Craft products & $\mathrm{n} / \mathrm{a}$ & $\rightarrow$ & \\
\hline & Honey & + & $\searrow$ & \\
\hline & Medicine & + & $\rightarrow$ & \\
\hline & Tourism & $\mathrm{n} / \mathrm{a}$ & $\rightarrow$ & \\
\hline \multirow[t]{2}{*}{ Coast } & Seafood & +++ & $\searrow$ & Sedimentation \\
\hline & Tourism & $\mathrm{n} / \mathrm{a}$ & $\rightarrow$ & $\begin{array}{l}\text { Deforestation } \\
\text { Increasing fisherman }\end{array}$ \\
\hline Crop land & Crop & +++ & $\searrow$ & $\begin{array}{l}\text { Land erosion } \\
\text { Low input }\end{array}$ \\
\hline
\end{tabular}

+++: Abundant; ++: Adequate; +: occasionally available; -: poor/rare; n/a data not available; $\uparrow$ Rapidly increasing; $\nearrow$ Increasing; $\rightarrow$ No change; \ Decreasing; $\downarrow$ Rapidly decreasing Developed from Miura, 2013, Assessment of natural resource and social capacity in Madagascar, unpublished

aims to highlight the potential and challenges in undertaking participatory sustainability research as a part of the environmental leadership development program.

Both groups had already gained an overall understanding of the trends in terms of environmental and ecosystem degradation through pre-visit literature review and interviews with stakeholders. Deforestation for charcoal production is prevalent, as is land reclamation to expand paddy and crop fields, and lumber extraction. In Ambatondrazaka, it is evident that deforestation causes siltation and sedimentation in irrigation channels and paddy fields, and reduces paddy field productivity. Due to the reduced rice productivity coupled with an increasing demand for rice, local farmers and villagers resort to forest destruction and land reclamation. A series of such behaviors constitutes a so-called "poverty-environment degradation vicious cycle" (Aggrecy et al. 2010). Based on the outcomes of the field surveys, assessments were also made of overall ecosystem service status and trends covering major ecosystem services, although the assessments were not exhaustive (Table 19.2).

Soil surveys were undertaken to examine the potential correlation between the land use practice and soil conditions, with a particular emphasis on whether land was excavated or under non-tillage cultivation (YNU-SLER 2013b). The groups conducted their soil survey on the assumption that soil conditions would be improved by conservational land use in the form of non-tillage farming or grass coverage of slopes for soil erosion control. It was assumed that the positive impacts on soil conditions could be shown by: (1) an optimal level of soil $\mathrm{pH}$, or marginal deviation from the optimal $\mathrm{pH}$ level (expressed by "6.5- $\mathrm{pH}$ " when $\mathrm{pH}$ was lower than 6.5 , and by " 0 " when $\mathrm{pH}$ was in a range of 6.5-7); (2) high electric conductivity; (3) high transparency of water containing dissolved soil; (4) a low level of soil hardness; and (5) low soil weight per unit. The results obtained in the soil inspection in the SAVA region concurred with the original assumption, as shown in Table 19.3. 
Table 19.3 Soil analysis—SAVA region Correlation with non-tillage land use history-24 locations of 12 sites

\begin{tabular}{llll}
\hline Variables & Data & Expectation & $\begin{array}{l}\text { Correlation } \\
\text { coefficient }\end{array}$ \\
\hline $\mathrm{pH}$ & $6.5-\mathrm{pH}(\mathrm{pH}<6.5)$ & Low & 0.2795 \\
& 0 when $\mathrm{pH}$ is 6.5-7 & & \\
Electric conductivity & $\mathrm{mS} / \mathrm{cm}$ (millisiemens per centimeter) & High & 0.3069 \\
$\begin{array}{l}\text { Transparency of dissolving } \\
\quad \text { water }\end{array}$ & $\begin{array}{c}\text { Measures from 1 to 9 with 9 } \\
\text { for highest transparency }\end{array}$ & High & 0.3941 \\
Hardness & Higher number for higher hardness & Low & 0.2677 \\
Weight/100 cc & Gram & Low & 0.2726 \\
\hline
\end{tabular}

Optimal range of $\mathrm{pH}$ is between 6.5 and 7 (Thermo Fisher Scientific n.d.)

Note: $\mathrm{pH}$ was less than 7 in all sites

Table 19.4 Social survey_Ambatondrazaka and SAVA areas Highlights (1)

\begin{tabular}{|c|c|c|c|c|c|c|}
\hline $\begin{array}{l}\text { Average monthly salary } \\
\text { (USD } 1=\text { MGA 2,200) }\end{array}$ & $<20 \mathrm{k}$ & $20-60 \mathrm{k}$ & $60-200 \mathrm{k}$ & $200-400 \mathrm{k}$ & $400-800 \mathrm{k}$ & $>800 \mathrm{k}$ \\
\hline \multicolumn{7}{|l|}{ Ambatondrazaka area $(n=32)$} \\
\hline Household no. & 7 & 12 & 9 & 3 & 1 & 0 \\
\hline Accumulative $\%(\mathrm{n}=32)$ & 22 & 59 & 88 & 97 & 100 & NA \\
\hline \multicolumn{7}{|l|}{ SAVA area $(n=32)$} \\
\hline Household no. & 9 & 12 & 6 & 3 & 0 & 0 \\
\hline Accumulative $\%(\mathrm{n}=32)$ & 30 & 70 & 90 & 100 & NA & NA \\
\hline Number of children & $\leqq 2$ & $3-4$ & $5-6$ & $7-8$ & 9 & 10 \\
\hline \multicolumn{7}{|l|}{ Ambatondrazaka area $(\mathrm{n}=32)$} \\
\hline $\begin{array}{l}\text { Household no. } \\
\text { Average } 3.2 / \text { household }\end{array}$ & 15 & 10 & 7 & 3 & NA & NA \\
\hline $\begin{array}{l}\text { SAVA area }(\mathrm{n}=32) \\
\text { Household No. } \\
\text { Average } 4.6 / \text { household }\end{array}$ & 7 & 8 & 10 & 3 & 2 & 1 \\
\hline Education & None & Elementary & $\begin{array}{l}\text { Elementary + } \\
\text { Junior High }\end{array}$ & $\begin{array}{l}\text { High } \\
\text { school }\end{array}$ & $\begin{array}{l}\text { Voca- } \\
\text { tional }\end{array}$ & $\begin{array}{l}\text { Univer- } \\
\text { sity }\end{array}$ \\
\hline $\begin{array}{l}\text { Ambatondrazaka area } \\
\quad(\mathrm{n}=35)\end{array}$ & 2 & 7 & 6 & 11 & 7 & 2 \\
\hline SAVA area $(n=27)$ & 1 & 9 & 11 & 6 & 0 & 0 \\
\hline
\end{tabular}

The soil samples taken at the site with the history of non-tillage land use demonstrated the projected coefficiency with the soil condition factors.

The groups also undertook questionnaire surveys to understand the socioeconomic conditions of people living in the sites visited. The questions encompassed household income level, the number of children in each household, and education history. The questions also included a self-assessment of the environment and invited suggestions for possible interventions to arrest environmental degradation and promote the restoration of the environment and ecosystems (Tables 19.4 and 19.5). 
Table 19.5 Social survey—Ambatondrazaka and SAVA areas Highlights (2)

\begin{tabular}{|c|c|c|c|c|c|c|}
\hline & \multicolumn{3}{|c|}{ Ambatondrazaka area } & \multicolumn{3}{|c|}{ SAVA area } \\
\hline & Agree & Disagree & Do not know & Agree & Disagree & Do not know \\
\hline Promoting environmental education & 33 & 1 & 0 & 31 & 0 & 0 \\
\hline Enforcing penalty on illegal logging & 31 & 0 & 0 & 31 & 1 & 0 \\
\hline $\begin{array}{l}\text { Giving more budget for government's } \\
\text { monitoring of the environment }\end{array}$ & 22 & 7 & 1 & 28 & 1 & 1 \\
\hline Raising tax on the sales of charcoal & 13 & 17 & 0 & 11 & 6 & 3 \\
\hline Increasing the tax on land use & 4 & 23 & 0 & 6 & 16 & 5 \\
\hline $\begin{array}{l}\text { Increasing the government's subsidy } \\
\text { for tree plantation }\end{array}$ & 30 & 1 & 0 & 31 & 0 & 0 \\
\hline $\begin{array}{l}\text { Encouraging private sector support } \\
\text { for tree plantation }\end{array}$ & 29 & 0 & 2 & 23 & 2 & 0 \\
\hline $\begin{array}{l}\text { Nothing we can do to improve } \\
\text { the environment }\end{array}$ & 0 & 27 & 5 & 1 & 16 & 0 \\
\hline
\end{tabular}

Table 19.6 Recent development in environment/natural resource management in SAVA area

\begin{tabular}{|c|c|c|c|c|c|c|c|c|}
\hline 2004 & 2005 & 2006 & 2007 & 2008 & 2009 & 2010 & 2011 & 2012 \\
\hline \multicolumn{9}{|c|}{ Masoala National Park deforestation (ha) } \\
\hline- & - & - & 45 & - & 5.5 & 40.5 & 17 & 9.25 \\
\hline \multicolumn{9}{|c|}{ Illegally logged trees (no.) } \\
\hline 212 & 182 & 165 & 165 & 36 & 6970 & 4163 & 853 & 91 \\
\hline \multicolumn{9}{|c|}{ Illegally captured lemurs (no.) } \\
\hline 23 & 7 & 10 & 2 & 6 & 11 & 42 & 91 & 13 \\
\hline
\end{tabular}

YNU-SLER (2013b)

The outcome of the questionnaire surveys $(n=62)$ showed that $88 \%$ of respondents regarded the surrounding environment as either severely degraded or degraded, and $87 \%$ regarded the forests as severely depleted or depleted. Respondents at an income level of less than one dollar per day accounted for $70 \%$. The average fertility rate was in the range of 3.2-4.6 per household, which was equivalent to the national average of 4.5 . With regard to education, $58 \%$ of the respondents had completed no more than junior high school. In terms of interventions to arrest environmental degradation and promote restoration of the already-degraded environment, almost all the respondents supported the promotion of environmental education and enforcement of a penalty on illegal logging. On the other hand, only $48 \%$ supported the idea of raising the tax on sales of charcoal, while just $19 \%$ supported the idea of increasing the tax on land use. It showed that the options for generating additional payments on the part of local people were not favored.

It is also interesting to note the people's understanding on the causes of lavakar or landslides. By interviewing experts and local people, and observing sites, the groups discovered that massive landslides occur in Madagascar due to a mixture of excessive logging and deforestation (Table 19.6), and tectonic movement. It was explained that in the process of illegal logging and deforestation, the root systems of the trees degrade or disappear and create small spaces in the soil. Rainwater 
Table 19.7 Social capacity assessment—Madagascar highlights

\begin{tabular}{|c|c|c|c|c|c|c|c|c|c|c|c|}
\hline \multirow{3}{*}{$\begin{array}{l}\text { Actor } \\
\text { Government }\end{array}$} & \multicolumn{11}{|c|}{ Factor } \\
\hline & \multicolumn{2}{|c|}{$\begin{array}{l}\text { Policy } \\
\text { and law }\end{array}$} & \multicolumn{2}{|c|}{ Staff } & Budget & \multicolumn{2}{|c|}{$\begin{array}{l}\text { Knowledge } \\
\text { and } \\
\text { technology }\end{array}$} & \multicolumn{2}{|c|}{$\begin{array}{l}\text { Law } \\
\text { enforce- } \\
\text { ment }\end{array}$} & \multicolumn{2}{|c|}{$\begin{array}{l}\text { Capacity } \\
\text { building }\end{array}$} \\
\hline & + & $\searrow$ & - & $\searrow$ & - & + & $\searrow$ & - & $\searrow$ & - & $\searrow$ \\
\hline Firms and Industry & + & $\rightarrow$ & + & $\rightarrow$ & + & ++ & $\rightarrow$ & + & $\rightarrow$ & + & $\rightarrow$ \\
\hline INGOs/NGOs & ++ & $\rightarrow$ & + & $\rightarrow$ & + & ++ & $\rightarrow$ & ++ & $\searrow$ & + & $\rightarrow$ \\
\hline
\end{tabular}

+++: Abundant; ++: Adequate; +: Minimal; -: poor/rare; n/a data not available; $\uparrow$ Rapidly increasing;

$\nearrow$ Increasing; $\rightarrow$ No change; \ Decreasing; $\downarrow$ Rapidly decreasing

Developed from Oo and Aung 2013, unpublished

intrudes into such spaces and makes soil structures fragile. Such processes cause lavakar or landslides, possibly prompted by tectonic movement. The relative weights to be given to the various interventions for arresting lavakar therefore depend on whether people emphasize deforestation or tectonic movement as the major cause of lavakar. In the questionnaire surveys, 35 respondents indicated slash and burn as a major cause of lavakar, followed by logging (32), heavy rain (9), gravity (7), and tectonic movement (2). This result indicates that the local people have a reasonable level of understanding with regard to the causes of lavakar and there is potential to create a basis for undertaking collective actions to arrest lavakar and restore the degraded environment.

In the interviews with experts, officials, and local stakeholders, the groups strived to collect information on social capacity for managing the environment and ecosystems. The 2009 political crisis had compelled the Government of Madagascar to resort to austere fiscal and administrative policies, particularly in the environment and forestry sectors. The budget and the number of staff for the Ministry of Forestry and Environment had been cut substantially as donor countries had suspended economic assistance, except in humanitarian areas. They had done so on the grounds that the presidential election conducted in 2009 was not consistent with constitutional procedures and was considered to be a coup d'état or unconstitutional change of government. A democratic and constitutional election was planned thereafter and the first round of the presidential election was held on October 25, 2013, with the involvement of international election monitoring. The second and final round of the presidential election is planned to be held on December 20, 2013. The process of electing a president in a manner that satisfies constitutional requirements and internationally acceptable procedures is expected to ameliorate the current international financial assistance to Madagascar. Yet, as of October 2013, donor countries had not yet restored their economic assistance to the levels seen prior to 2009, and securing the finances for environment and forestry governance remained an arduous task. With the reduction in financial inflows from overseas, public-sector, business, and civil society organizations all continue to face economic constraints.

Based on information collected during the field surveys, questionnaires, and interviews, the social capacity for environmental and ecosystem management was assessed following the actor-factor analysis approach by analyzing the levels of (1) policy and law, (2) staff, (3) budget, (4) knowledge and technology, (5) law enforcement, and (6) 
capacity building (Table 19.7). While a certain level of accumulated knowledge and application of technology was acknowledged, the overall trend of social capacity was at a level that was barely sufficient and was either declining or unchanging.

\subsection{Lessons Learned and Ways Forward to Improve the Impacts of Participatory Sustainability Research in the Environmental Leadership Development Program}

The field surveys were conducted very productively and efficiently within the time and resource constraints, and the outcome of the surveys attracted reasonable praise at the outcome presentation symposium. However, a number of challenges could be pointed out, and some reflections could be also noted, to enhance the impacts of participatory sustainability research in the environmental leadership development program in the future.

The field surveys were useful for understanding the local socio-economic and environmental conditions and gave the outsider visitors further ideas about possible support to improve natural resource use and promote alternative sustainable livelihoods. However, the surveys could not reach the stage of planning and undertaking consultations on possible interventions or pilot projects. This is in contrast with the SLER programme's involvement in Rikuzentakata-a city hit by the 2011 great disaster in Japan. SLER programme students, faculty members, and partners have visited Rikuzentakata four times over the period of 2011-2013. Each visit to Rikuzentakata was for 2-3 days. One pilot initiative undertaken during the visit in September 2012 was to collect sprouts of endogenous evergreen broad leaved tree species. A total of 34 students and faculty members participated in the visit and collected 477 seedlings of three tree species, namely Persia/Machilus thumbergii (445), Camellia japonica (30), and Eurya japonica (2). In September 2013, 27 faculty members and students returned and observed that 40 seedlings had survived over the year out of about 200 that were transplanted into the ground in October 2012. The survival rate of the collected and transplanted seedlings was estimated to be $20 \%$. There were an additional 280 seedlings transplanted into the garden of the public community house, but they were inadvertently all removed in the spring of 2013. In 2013, about 400 seedlings of Persia thumbergii and Camellia japonica were collected and transplanted into seedling pots. The students reported afterwards that their proactive involvement in concrete pilot initiatives such as the collection and transplantation of evergreen broad leaved tree species gave them a sense of participation in the local process, which in this case involved reconstruction and community empowerment. It also made them feel a sense of partnership with local people, and they believed that they were making useful contributions to local communities. Further details need to be elaborated elsewhere, but the students also witnessed that the local people showed more positive reactions to the initiative of producing evergreen broad leaved tree seedlings in the midst of their preoccupation 
with the restoration of the coastal pine woodland-the legendary scenic site in the locality that had been completely destroyed in the tsunami of 2011.

Funding is critical for undertaking effective participatory sustainability research, and not only is it needed to cover costs, but it must also be flexible enough to allow adaptive management of research activities (Mackenzie et al. 2012). Pilot initiatives need to be planned and implemented based on an appraisal of local socio-economic and environmental conditions. A broad range of possible activities and proposed procedures could be suggested, but such plans and the outcomes to be expected may not necessarily be stated rigidly as they will need to be adjusted in accordance with the findings and outcomes of local consultations.

It is vital to put in place an institution that can promote participatory sustainability action research as a part of leadership development programs in higher education. There are a number of centers and institutions established within, or in partnership with, universities to promote sustainability science research in higher education (CLiGS, CML, GMV, and the Sustainability Institute). There was one case in which an NGO was established to support sustainability action research (Harada Laboratory 2012). The operation of such centers or institutions plays an important role in establishing links between students and experts on a wide range of sustainability and environmental issues and in supporting trans-disciplinary science and its pragmatic application (MOEJ 2007). If such a center or institution could be established to support the type of activities undertaken within YNU through the SLER programme, it would be highly effective, offering more reliable continuity and adaptive management of research and operational activities.

Integration of research and education is another essential factor. A number of the educational courses can be inter-linked with each other, but the students do not necessarily take such inter-linked courses in their entirety, and the universities or faculties do not design and offer courses based on a step-by-step approach. In the case of the SLER programme, there were students who participated in the intensive course on integrated risk management and resilience and thereafter participated in the course on Asia-Africa II that mainly comprised a group study tour to Madagascar. However, not all students take both courses, although both courses employ the same approach applied in Japan and an overseas developing country. The course on local risk and resource management was an additional course that was used to follow up on the field studies undertaken in Madagascar in particular, but again the students attending the Asia-Africa II course do not necessarily attend the local risk and resource management course.

Meanwhile, further analysis is required on the linkages between individual research for the students' degree dissertations on the one hand, and group research, other course work, or leadership development program activities on the other. While research methods and approaches may be shared or related, they do not necessarily correspond to each other directly. Linking the two sides of the equation is no straightforward task, as the students have diverse interests and areas of focus even though they all address environment and sustainability issues.

Environment and sustainability education is still in its developmental stages and the supporting faculty and administrative members operate outside the university's 
main budget, relying on subsidies from the central government. In the case of the SLER programme, this means the Japanese Ministry of Education, Culture, Sports, Science and Technology (MEXT). It is essential to integrate such supporting staff and operational costs into the core staff and budget of the university in order to ensure continuity, up-scaling, and constructive evolution, as well as to enhance the impact of sustainability science and leadership development.

There are a number of potential and emerging opportunities for undertaking effective sustainability science and leadership development in higher education; universities and academics can do still more to create links between science, policy, and stakeholders in order to build a sustainable society. Both providers and receivers of sustainability education need to reconsider their thinking and approaches to help research and education transform themselves to increase their capacity to forge sustainability in society. Good practice and past trial experiences must be shared more widely and substantively and capitalized upon to develop effective policies, programs, curricula, institutions, and partnerships for fostering sustainability science and leadership development.

Open Access This article is distributed under the terms of the Creative Commons Attribution Noncommercial License which permits any noncommercial use, distribution, and reproduction in any medium, provided the original author(s) and source are credited.

\section{References}

Adandedjan C, Niang A (2006) Forging links between research and development in the Sahel: the missing link. In: Bessette G (ed) People, land and water - participatory development communication for natural resource management. Earthscan, London, pp 217-220

Aggrecy N, Wambugu S, Karugia J, Wanga E (2010) An investigation of the poverty-environmental degradation nexus: a case study of Katanga Basin in Uganda. Res J Environ Earth Sci 2(2):82-88

Asia Pacific Forum for Environment and Development (APFED) (2010) APFED II Final Report. http://www.apfed.net/apfed2/APFED_II_Final_Report_for_CD.pdf. Accessed 28 Sept 2013

Blackstock LD, Kelly GJ, Horsey BL (2007) Developing and applying a framework to evaluate participatory research for sustainability. Ecol Econ 60:726-742

Center for Leadership in Global Sustainability (CLiGS) (n.d.) About. http://vatech.beekeeperdev. com/about/. Accessed 5 Oct 2013

Centre for Environment and Sustainability (GMV) (n.d.) Collaboration for sustainable development. http://www.gmv.chalmers.gu.se/english/. Accessed 4 Oct 2013

Chambers R (1994a) The origins and practice of participatory rural appraisal. World Dev 22(7):953-969

Chambers R (1994b) Participatory rural appraisal (PRA): challenges, potentials and paradigm. World Dev 22(10): 1437-1454

Chambers R (2007) From PRA to PLA and pluralism: practice and theory. Institute of Development Studies, Brighton

Dedeurwaerdere T (2013) Transdisciplinary sustainability science at higher education institutions: science policy tools for incremental institutional change. Sustainability 5:3783-3801

Harada Laboratory (2012) Report on the activities of PGV in Indonesia. http://www.u-hyogo.ac.jp/ shse/harada/PGV_Web/indonessia.pdf. Accessed 5 Oct 2013 
Institute of Environmental Sciences (CML) (n.d.) General information - overview of activities of Institute of Environmental Sciences. http://www.cml.leiden.edu/organisation/about/aboutcml. html. Accessed 4 Oct 2013

Kelvin SHP, Balmoford A, Bradbury RB, Brown C, Butchart SHM, Hughes FMR, Stattersfield A, Thomas DHL, Walpole M, Bayliss J, Gowing D, Jones PGJ, Lewis SL, Mulligan M, Pandeya B, Stratford C, Thompson JR, Turner K, Vira B, Willcock S, Birch JC (2013) TESSA: a toolkit for rapid assessment of ecosystem services at sites of biodiversity conservation importance. Ecosyst Serv 5:e51-e57

Kobayashi M (2012) Forging policy and institutional frameworks to promote access to environmental information. In: Institute for Global Environmental Strategies (IGES) (ed) Institute for global environmental strategies. IGES, Hayama, pp 34-53

Mackenzie J, Tan PL, Hoverman S, Baldwin C (2012) The value and limitations of participatory action research methodology. J Hydrol 474:11-21

Matsuoka S, Murakami K, Aoyama N, Takahashi Y, Tanaka K (2008) Capacity development and social capacity assessment (SCA)

Millennium Ecosystem Assessment (2005) Ecosystems and human well-being: synthesis. Island Press, Washington, DC

Ministry of Environment, Japan (MOEJ) (2007) On-going overseas research. Committee on Environmental Leadership Development in Higher Education for a Sustainable Asia. http:// www.env.go.jp/council/34asia-univ/y340-04/mat07.pdf. Accessed 3 Oct 2013

Ostrom E (1990) Governing the commons. Cambridge University Press, Cambridge

Ostrom E (2000) Collective action and the evolution of social norms. J Econ Perspect 14(3): $137-158$

Petkova E, Maurer C, Henninger N, Irwin F, Coyle J, Hoff G (2002) Closing the Gap: information, participation and justice in decision-making for the environment. World Resource Institute, Washington, DC

Rockström J, Steffen W, Noone K, Persson K, Chapin FS III, Lambin E, Lenton TM, Scheffer M, Folke C, Schellnhuber H, Nykvist B, De Wit CA, Hughes T, van der Leeuw S, Rodhe H, Sölin S, Snyder PK, Costanza R, Svedin U, Falkenmark M, Karlberg L, Corell RW, Fabry VJ, Hansen J, Walker B, Liverman D, Richardson K, Crutzen P, Foley J (2009) Planetary boundaries: exploring the safe operating space for humanity. Ecol Soc 14(2):32

Sow F, Adjibade A (2006) Experimenting with participatory development communication in West Africa. In: Bessette G (ed) People, land and water - participatory development communication for natural resource management. Earthscan, London, pp 153-157

Sustainability Institute (n.d.) Overview. http://www.sustainabilityinstitute.net/about/overview. Accessed 4 Oct 2013

Takeuchi K (2013) Science and innovation for a sustainable future: the role of sustainability science. International symposium on developing leaders for managing risks and promoting sustainability toward establishing a resilient and sustainable society, Tokyo, 23 September 2013. http://www.sler.ynu.ac.jp/node/592. Accessed 23 Sept 2013

Thermo Fisher Scientific (n.d.) Gardening \& Soil pH. www.eutechinst.com/tips/ph/15_soil_ph. pdf. Accessed 2 Oct 2013

United Nations General Assembly (UNGA) (1992), A/CONF.151/26 (Vol. I). Report of the United Nations conference on environment and development, 12 August 1992

United Nations General Assembly (UNGA) (2012). Resolution 66/288. The future we want, 11 September 2012

World Resource Institute (WRI) (2013) Jakarta declaration for strengthening the right to environmental information for people and the environment, 1 May 2013. http://pdf.wri.org/jakarta declaration_for_strengthening_right_to_environmental_information.pdf

Yasunari T (2013) Future earth - a new international initiative toward global sustainability. International symposium on developing leaders for managing risks and promoting sustainability toward establishing a resilient and sustainable society, Tokyo, 23 September 2013. http:// www.sler.ynu.ac.jp/node/592. Accessed 23 Sept 2013 
Yokohama National University-Leadership Development Programme For Sustainable Living With Environmental Risks (YNU-SLER) (2013a) Newsletter, Vol. 6, March 2013. http://www.sler. ynu.ac.jp/en/newsletter. Accessed 1 Oct 2013

Yokohama National University-Leadership Development Programme for Sustainable Living with Environmental Risks (YNU-SLER) (2013b) Report - Asia-Africa II Group Study Tour to Madagascar https://sites.google.com/site/ynuslermadagascar/final-report. Accessed 28 Oct 2013 